\title{
Growth, development and viability of Metarhizium anisopliae on media with various nutrient sources
}

\author{
S.D. PATIL ${ }^{* 1}$, J.R. KADAM ${ }^{2}$, A.G. CHANDELE ${ }^{2}$, S.S. WAGH ${ }^{2}$ AND R.S. JADHAV ${ }^{2}$ \\ ${ }^{1}$ Department of Entomology, Agricultural Research Station, Niphad, NASIK (M.S.) INDIA \\ ${ }^{2}$ Department of Entomology, Mahatma Phule Krishi Vidhyapeeth, Rahuri, AHMEDNAGAR (M.S.) INDIA
}

\section{ARITCLE INFO}

$\begin{array}{ll}\text { Received } & : 26.07 .2012 \\ \text { Revised } & : 23.08 .2014 \\ \text { Accepted } & : 04.09 .2014\end{array}$

KEY WORDS :

Metarhizium anisopliae, Yeast extract, Biomass, Colony forming unit

\begin{abstract}
The entomopathogenic fungus, Metarhizium anisopliae (Metschinikoff) Sorokin was mass produced in different liquid media. The nine media of various nutrient sources were evaluated to find out the most suitable medium for growth, biomass and viability of M.anisopliae. Sabouraud's dextrose broth with yeast extract proved to be the superior which gave significantly highest cfu $\left(12.33 \times 10^{8} / \mathrm{ml}\right)$ and biomass $(7.20 \mathrm{~g})$. The next best medium was Sabouraud's maltose broth with yeast extract and potato dextrose broth with yeast extract which registering cfu count of $\left(10.33 \times 10^{8}\right.$ and $\left.10.67 \times 10^{8} \mathrm{cfu} / \mathrm{ml}\right)$ and biomass $(6.27$ and $5.73 \mathrm{~g})$, respectively. The lowest $(48.33 \%)$ medium surface coverage and least biomass $(1.57 \mathrm{~g})$ and cfu $\left(4.33 \times 10^{8} /\right.$ $\mathrm{ml}$ ) were registered in medium with malt extract. Thus, considering growth, development and viability of M.anisopliae, Sabouraud's dextrose broth with yeast extract (SDY) emerged as the most potential medium for biomass production.
\end{abstract}

How to view point the article : Patil, S.D., Kadam, J.R., Chandele, A.G., Wagh, S.S. and Jadhav, R.S. (2014). Growth, development and viability of Metarhizium anisopliae on media with various nutrient sources. Internat. J. Plant Protec., 7(2) : 420-423. 